\title{
Analysis of Main Influence Factors for Housing Prices
}

\author{
Congjun Rao, Yangqiu Ge \\ College of Mathematics and Physics, Huanggang Normal University, \\ Huanggang 438000, China \\ cjrao@163.com
}

Keywords: Housing price; Analysis of main influence factors; multiple linear regression

Abstract. Housing price problem is an important economic and social issue of widespread concern, which affects the life quality of urban residents and also affects the continued steady growth of national economy. Based on method of multiple linear regression analysis, this paper studies the relationship between housing prices and the influencing factors in the aspects of demand and supply, and identifies the main factors of influencing the housing prices. It tries to provide the valuable reference for the government to regulate the housing market effectively.

\section{Introduction}

The modern real estate industry has become a pillar industry of Chinese national economy, and the housing price is the key in the real estate industry. The housing price level is not only related to the living standards of the masses, but also related to the global economic development. However, in recent years, due to the cyclical and regional real estate development, there is imbalance in the market of supply and demand. Together with the increased raw material prices and costs, the house price is becoming more and higher. The housing price is an extremely complex issue, to study the main influence factors and to find out the change rules have important theoretical and practical significance to promote the sustainable and healthy development of the residential real estate market.

Many scholars presented some valuable results on the study of housing price. Zhao [1] used the factor analysis method to analyze twelve influence factors for housing price, and finally selected two main influence factors. She also pointed out that China's real housing prices have been gradually rising. Guo and Yuan [2] studied the interactions relationship between real estate market and interest rates from 1998 to 2008, and the results indicated that there is a co-integration relationship between interest rates and housing price. Li studied the panel data of 30 provinces and cities from 2000 to 2011, and used the EBA (extreme bounds analysis) model to explore the "robustness" factors which influence the housing prices. The conclusion is drawn that the land price, the cost of completion housing, population and urban and rural incomes are four main influence factors for the housing price. Xue [3] pointed out that the housing market has always maintained a good momentum of development since the Chinese real estate industry has entered the commercialization stage. Guo and Wang [4] established a dynamic econometrics model to analyze the main influence factors for housing prices, and pointed out that there is a long-term equilibrium relationship between housing prices and the housing supply and demand variables. Li [5] selected some important indexes which influence housing prices, and used statistical software to analyze the factor analysis from the original data. Then four representative factors, i.e., economic factor, the real estate factor, transportation environmental factor, the expected factor are selected. Liu [6] reviewed and summarized the latest research on foreign housing price factors from the perspective of supply-demand balance, and the related literature was summarized in terms of land, income, tax, financial, location and other domestic achievement.

Based on existing results, this paper studies the relationship between housing price and its influencing factors based on method of multiple linear regression analysis. The aim is to find out the main factors of influencing the housing prices and to provide the valuable reference for the government to regulate the housing market effectively. 


\section{Analysis of Main Influence Factors for Housing Prices}

Changes in supply and demand are the direct factors for the housing price change. Now we list some factors which influence supply and demand of houses.

For the demand, the following influence factors are given.

$A_{1}$ Sales area of resident. Sales area of resident will affect the housing price to a certain extent. Take the related data of real estate market in Wuhan City as an example, by analyzing the historical data of sales area of resident and completed residential area in 2004-2014 in Wuhan City, it can be seen that sales area of resident is approximately equal to completed residential area every year.

$A_{2}$ Per-capita income. Increase in per-capita income will cause the rise of housing prices to from two aspects. On the one hand, increase in per-capita income is inseparable from economic development, and economic development means investment, production and business activities, etc. become active, thus the demand for shopping malls, factories, offices, etc. are increasing, which bring to the rise in house prices. On the other hand, rising incomes and improved living standards will bring to higher living standards for people.

$A_{3}$ Quantity of urban population. Quantity of urban population plays a tremendous influence affect on housing price. The influence can be divided into two categories. The first one is direct influence, i.e., Higher quantity of urban population will bring to higher demand of house. The second one is the indirect influence, i.e., higher quantity of urban population will bring to higher demand of house.

$A_{4}$ Bank Rate. Interest rate affects housing prices from the aspects of supply and demand. First, from the aspect of supply, the interest rate reflects the cost of funds, and it directly affects the total cost of development. When interest rates rise, the cost of funds directly leads to higher prices.

$A_{5}$ Sales area of resident. Sales area of resident will affect the housing price to a certain extent. Take the related data of real estate market in Wuhan City as an example, by analyzing the historical data of sales area of resident and completed residential area in 2004-2014 in Wuhan City, it can be seen that sales area of resident is approximately equal to completed residential area every year.

Housing Cost. Under certain circumstances that the supply and demand is fixed, the rising of land and construction materials are important factors in driving up housing prices. As land resources are limited, so the changes of housing price will not cause a large change in supply elasticity.

For the supply, the following influence factors are given.

Price level. The main indie of the price level is the consumer price index (the CPI), which is a reflection of the residents to purchase and relative number of trends and changes in volatility. The index covers all types of consumer prices, both urban and rural residents daily needs, but also includes a variety of people's lives are closely related to the price of services.

The gross domestic product (GDP). GDP refers to the final results of production activities of a country (or region) at market prices in a given period. GDP growth was accompanied by the rise of the whole society investment, and indirectly affects the rate change.

Completed residential area, which represents the supply of real estate in that year. The sales area increased, and the need for more people to buy a house. When the completed residential area reduces or the sales area increases, this means demand exceeds supply, thus the housing prices rises.

\section{Quantitative Analysis of Main Influence Factors for Housing Prices}

In this section, we present a quantitative analysis model based on multiple linear regression to find out the main influence factors for housing prices.

$$
y=a_{0}+a_{1} x+a_{2} x^{2}+\mathrm{L}+a_{k} x^{k}(k=1,2, \mathrm{~L}, n)
$$

where $y$ denotes the housing price, and $x_{1}, x_{2}, \mathrm{~L}, x_{k}$ denotes the influence factors for housing prices such as per-capita income, quantity of urban population, bank rate, and so on, $a_{0}$ is a constant, $a_{1}, a_{2}, \mathrm{~L}, a_{k}$ are the regression coefficients, and $b$ is a regression remainder. 
Now we take the related data of real estate market in Wuhan City as an example to make an empirical analysis from the aspects of demand and supply respectively. The relative data are listed in Table 1.

Table 1. The related data of demand factors in Wuhan City

\begin{tabular}{cccccc}
\hline Year & $\begin{array}{c}\text { Housing Price } \\
\text { (Yuan) }\end{array}$ & $\begin{array}{c}A_{1} \\
\left(10^{4} \text { Square }\right. \\
\text { meters) }\end{array}$ & $\begin{array}{c}A_{2} \\
\text { (Yuan) }\end{array}$ & $\begin{array}{c}A_{3} \\
\text { (Million) }\end{array}$ & $\begin{array}{c}A_{4} \\
(\%)\end{array}$ \\
\hline 2004 & 2463 & 614 & 9564 & 785 & 6.1 \\
2005 & 2986 & 834 & 10850 & 801 & 6.2 \\
2006 & 3535 & 909 & 12360 & 819 & 6.8 \\
2007 & 6 & 1070 & 14358 & 828 & 7.2 \\
2008 & 4681 & 683 & 16712 & 833 & 7.9 \\
2009 & 5199 & 1041 & 18385 & 836 & 7.6 \\
2010 & 5550 & 1095 & 20806 & 837 & 5.4 \\
2011 & 6676 & 1085 & 23738 & 827 & 6.2 \\
2012 & 6895 & 1693 & 27061 & 822 & 6.7 \\
2013 & 7238 & 1750 & 29821 & 822 & 6.2 \\
2014 & 7806 & 1979 & 33270 & 827 & 6.2 \\
\hline
\end{tabular}

Here we use the software of SPSS to calculate the model (1), the results are given in Table 2. Table 2. The calculating result

\begin{tabular}{cccccc}
\multirow{2}{*}{ Model } & Quadratic & Df & Mean & F & Sig. \\
& sum & square & & \\
Choose $A_{1}$ to $A_{4}$ & Regression & 31493156.4 & 4 & & \\
& Residual & 518997.9 & 6 & 91.021 & $.000^{\mathrm{a}}$ \\
& Total & 32012154.4 & 10 & & \\
Not choose $A_{3}$ & Regression & 31123222.6 & 3 & & \\
& Residual & 888931.8 & 7 & 137.7 & .000 \\
& Total & 32012154.4 & 10 & & \\
Not choose $A_{3}$ & Regression & 31490893.883 & 3 & & \\
& Residual & 521260.6 & 7 & 140.9 & $.000^{\mathrm{a}}$ \\
& Total & 32012154.4 & 10 & & \\
Not choose $A_{1}$ & Regression & 31478591.3 & 3 & & \\
& Residual & 533563.06 & 7 & 137.7 & $.000^{\mathrm{a}}$ \\
& Total & 32012154.4 & 10 & & \\
Not choose $A_{2}$ & Regression & 28295799.6 & 3 & & \\
& Residual & 3716354.9 & 7 & 17.8 & $.001^{\mathrm{a}}$ \\
& Total & 32012154.4 & 10 & & \\
\hline
\end{tabular}

From Table 2, we can see that the Model 3 is optimal among five models, where $R=0.992$ and $R^{2}=0.984$. The adjustable $R^{2}$ is $R^{2}=0.977$, which means the fitting degree of regression model on the sample observations is better for Model 3. The value of $D-W$ is 2.181 , which means the independence between model variables is higher, and there is no multiple linear relationship among all variables. In addition, in model $3, F=140.964, P=0.000$, which means the regression model 3 is remarkable, and the relative variable values are obtained as follows.

$a_{0}=-13599.8, a_{1}=0.215, a_{2}=-0.226, a_{3}=18.073$.

Thus we can obtain the following functional relationship.

Housing price $=-13599.816+0.215 \times$ Per-capita income- $0.226 \times$ Sales area of resident $+18.073 \times$ Quantity of urban population.

Moreover, for the supply factors, we give following similar analytical method. 
Table 3. The related data of supply factors in Wuhan City

\begin{tabular}{lcccccc}
\hline Year & $\begin{array}{c}\text { Total fixed } \\
\text { investment } \\
\text { (billion } \\
\text { yuan) }\end{array}$ & $\begin{array}{c}\text { Housing } \\
\text { Price } \\
\text { (Yuan) }\end{array}$ & $\begin{array}{c}\text { Residential } \\
\text { investment } \\
\text { (Billion } \\
\text { yuan) }\end{array}$ & $\begin{array}{c}\text { Completed } \\
\text { residential area } \\
\text { (Thousands } \\
\text { square meters) }\end{array}$ & $\begin{array}{c}\text { GDP } \\
\text { (Billion } \\
\text { yuan) }\end{array}$ & CPI \\
\hline 2004 & 822.2 & 2462.7 & 613.9 & 613.9 & 151.2 & 103.3 \\
2005 & 1055.2 & 2986.2 & 834.2 & 834.2 & 249.1 & 102.7 \\
2006 & 1325.3 & 3535.3 & 908.9 & 908.9 & 321.3 & 101.4 \\
2007 & 1732.8 & 4515.8 & 1069.9 & 1069.9 & 483.1 & 104.1 \\
2008 & 2252.1 & 4680.5 & 683.2 & 683.2 & 319.8 & 105.7 \\
2009 & 3001.1 & 5198.5 & 1041.4 & 1041.4 & 541.4 & 99.4 \\
2010 & 3753.2 & 5550.0 & 1095.2 & 1095.2 & 606.0 & 103.6 \\
2011 & 4255.2 & 6675.9 & 1085.3 & 1085.3 & 654.3 & 105.2 \\
2012 & 5031.3 & 6895.4 & 1692.7 & 1692.7 & 858.2 & 102.8 \\
2013 & 6001.96 & 7238.0 & 1749.7 & 1749.7 & 896.7 & 102.4 \\
2014 & 7002.9 & 7806.0 & 1978.9 & 1978.9 & 1316.0 & 101.6 \\
\hline
\end{tabular}

We also use the software of SPSS to calculate the models, then we have

Housing price $=-8383.912+3.562 \times$ Residential investment $+3.876 \times$ Completed residential area $+1.023 \times \mathrm{GDP}+76.910 \times \mathrm{CPI}$.

\section{Conclusions}

This paper gives the quantitative analysis of the influential factors for the housing prices, and obtains the following conclusions. (1) In many influential factors for the housing prices, Per-capita income, Sales area of resident and Quantity of urban population are the main influential factors for the housing prices. This is from the aspect of demand. In the aspect of supply, Residential investment, Completed residential area and GDP are the main influential factors for the housing prices. Therefore, the management department in government can take some measures to control the housing prices from these main influential factors, and make the real estate market healthy functioning properly.

\section{Acknowledgments}

This work is supported by the Natural Science Foundation of Hubei Province (No.2014CFC1096), and the 2014 Key Project of Hubei Provincial Department of Education (No.D20142903).

\section{References}

[1] Y.S. Zhao, Influence factors analysis and prediction of real estate price, Statistics and Decision 409 (2014) 107-110.

[2] S.H. Guo, T.A. Yuan, Empirical study of interactive relationship for interest rate and real estate market, Journal of Regional Financial Research 1(2010) 46-50.

[3] B. Xue, Empirical analysis of influence factors for housing price in Jinan, Journal of Hebei University of Economics and Trade (Comprehensive Edition) 11 (2011) 25-26.

[4] B. Guo, Y. Wang, Influence factor research on real estate price based on dynamic econometrics model, Commercial Research 403 (2010) 175-177.

[5] C. Li, Analysis of influence factors for Chinese housing prices based on the factor analysis method, Economic Research Guide 90 (2010) 158-159.

[6] H.B. Liu, Mathematical Modeling and Experiment, Science press, Beijing, 2008. 